\title{
MICROBIOLOGICAL PROFILE OF THE NASAL CAVITY OF PROFESSIONALS FROM THE EMERGENCY SECTOR AND MOBILE URGENCY CARE SERVICE LOCALIZED IN A SOUTHWEST MUNICIPALITY OF GOIÁS
}

\author{
PERFIL MICROBIOLÓGICO DA CAVIDADE NASAL DE TRABALHADORES DO \\ SETOR DE EMERGÊNCIA E ATENDIMENTO MÓVEL DE URGÊNCIA DEUM \\ MUNICÍPIO DO SUDOESTE DE GOIÁS
}

\section{Cácia Régia de PAULA ${ }^{1}$; Bruno Bordin PELAZZA² ${ }^{2}$ Ludmila Grego MAIA $^{3}$; Patrícia de Sá BARROS $^{4}$; Marlene Martins ANDRADE ${ }^{5}$; Juliana Flávia Ferreira e Silva PARANAÍBA ${ }^{6}$; Guilherme Silva MENDONCA ${ }^{7 ;}$ Marinésia Aparecida do Prado PALOS ${ }^{8}$ \\ 1. Lecturer of the nursing course of the Federal University of Goiás - Jataí; 2. Lecturer of the nursing course of the Federal University of Goiás - Jataí; 3. Lecturer of the nursing course of the Federal University of Goiás - Jataí; 4. Lecturer of the nursing course of the Federal University of Goiás - Jataí; 5. Lecturer of the nursing course of the Federal University of Goiás - Jataí; 6 . Biologist, administrative technician at the Federal University of Goiás; 7. Nurse, Master and Doctorate by the Graduate Program in Health Sciences of the Faculty of Medicine of the Federal University of Uberlândia; 8. Lecturer of the nursing course of the Federal University of Goiás - Goiânia. caciaregia@gmail.com}

\begin{abstract}
The challenges concerning safety and quality at health institutions are phenomena documented by researchers the world over, such manifestations are the result of the newly found understanding in contemporary society of the rights attained by workers and/or users of such health-associated services. Thus, the detection of workers from Emergency Sectors and from the Mobile Urgency Care Service - SE/SAMU, carriers of pathogenic and multiresistant microorganisms, has been referred to as a possible strategy of prevention and reduction of Infections Related to Health Care - IRHC. The objective of this study was to analyze the microbiological profile of the nasal cavity of workers from the Emergency and Mobile Emergency Care Department of a municipality in the southwest of Goiás. A cross-sectional study of an epidemiological nature was performed, developed within the Emergency Services and the Mobile Urgency Care Services in a municipality situated in the southwest of Goiás. The collection of data occurred during the period of 07 May to 13 June of 2012 and was initiated with clarification as to the reasons for the project and later a form was given to the 51 participating workers. Following this, a sample was taken from the nasal cavity of each participant by means of a swab; these were collected in BHI tubes, and consequently incubated at $35^{\circ} \mathrm{C}$ for $18 / 24$ hours. Next, these samples were smeared in selective media cultures and processed by automation, the colonies that developed were previously identified and submitted to screening for the selection of identification evidence. Noteworthy was the fact that workers did not perform handwashing procedures correctly, which increased the possibility of infection by microorganisms, where the most frequent were $S$. epidermidis, followed by $S$. aureus. The pathogen $S$. hyicus, was also isolated, being that this pathogen is not natural to humans. Among the isolated microorganisms, the resistance profile to antimicrobials in 38 of these were analyzed. In light of such findings, it becomes necessary to produce clear projects of intervention and incorporation that are focused on the principles of safety and life quality of the worker from the area of health care. In particular, those from the Emergency Sector and Pre-Hospital Attendance of the municipal health network, which is in addition to providing feedback on teaching, research and care based on these principles.
\end{abstract}

KEYWORDS: Workers' Health, Microbial Resistance, Patient Safety.

\section{INTRODUÇÃO}

The professional health / patient relationship involves risks inherent in the direct provision of care, a fact that has been the subject of constant studies and surveillance, in view of the potential colonization by multiresistant microorganisms, especially Staphylococcus aureus, being this, the pathogen with greater prevalence in health institutions (LOPES et al, 2017;OMS, 2008).

The provision of care for long periods and the non-adherence of health professionals to standard precautionary measures makes these susceptible to colonization and consequent dissemination of microorganisms, which becomes a major management challenge in the area of health services (CARVALHO et al, 2016; LIMA et al, 2015).

For some time, the issue of safety and quality in health care institutions has been debated by researchers around the world. As an important milestone, the World Alliance for Patient Safety was set up by WHO at the $57^{\text {th }}$ World Health Assembly, which recommended that individual countries give 
greater attention to this particular issue. (OMS, 2008; ANVISA, 2011).

This alliance has as its objective to raise awareness and create political commitment in managers related to the area of health, in order to improve safety in health care, besides support countries that are developing public policies and practices toward patient safety across the world. In order that this safety reaches the desired efficiency, the health and life quality of workers should not be excluded. It was through this resolution that Latin countries started to move toward fulfilling the role through the taking of actions, as those set out in the Alliance (OMS, 2008; ANVISA, 2011).

Among those maintenance measures, which aim at producing a biologically safe work environment, one can include infection surveillance, where emphasis is given to the colonization of health workers by virulent microorganisms, and more specifically those that are multidrug-resistant. Studies with similar aims are frequent in industrialized countries, especially those that refer to the search for care quality indicators within the health environment (SIEGEL et al., 2007; OMS, 2009; PALOS et al., 2009).

The complexity of the themes that are involved in safety of the work environment demand professional handling, in that which concerns technical decision making, as well as in the areas concerning their administration, economy and operation. The different types of workers, especially managers and directors, looking to evaluate their position when faced with themes concerning work health and safety, need to analyze aspects of behavior during the working day, among others (ANVISA, 2010).

This should also extend across the health institution as a whole, especially when dealing with urgency and emergency services, for both pre and intrahospital, which is shown to be one of doors of entry for diseases into the Public Health System (SUS). Although these health service professionals follow busy and stressful routines, while still providing a service in situations that demand speed and agility, they should still follow health and safety practices in the workplace, set upon principles and regulations advertised through the health and safety program of the institution, with which the individual maintains a working relationship (ANVISA, 2010; MALTA et al., 2012).

Therefore, the detection of workers from Emergency Sectors and the Mobile Urgency Care Service - SE/SAMU, carriers of pathogenic and multiresistant microorganisms, has been referred to as a possible strategy of prevention and reduction in infections related to health care - IRHC. However, it needs to be highlighted that the most researched microorganism, as a colonizer on health workers, is Staphylococcus aureusmethicillin resistant (MRSA). Even though research on the colonization of bacteria from different groups, such as gram-negative, as well as fungus are rare, the relevance of the carriers of such agents within the health context needs a clear understanding (CRUZ, 2008; WOLF et al., 2008; PALOS et al., 2009).

The procedures performed on the user by health workers associated with emergency and mobile urgency care services, expose the health worker from SE/SAMU teams to occupational risks and work related accidents. This exposure involves biological, physical-ergonomic and psychosocial risk. The biological risk has the highest factor of impact, and is present when directly or indirectly handling materials that contain organic fluids, environmental surfaces, equipment, and/or users that are carriers of microorganisms resistant to antimicrobials. These risks increase in accordance with function performed by the team worker, to the degree at which they have contact with the patient (LOPES et al., 2008; DE LIMA, 2012).

Through the use of cross-sectional studies, one is able to identify prevalence rates for the occurrence of microorganisms and its relationship to clinical variables, thus opening the possibility of investigating risk factors and protection, besides establishing preventative and therapeutic measures, in order to minimize the transference of such microorganisms, and thus reduce the risk of infection (CARVALHO et al., 2016).

In light of the aforementioned, this study aimed to analyze the prevalence of microorganism occurrence in the nasal cavity of workers from SE/SAMU, and the susceptibility profile of such to antimicrobials.

\section{MATERIAL AND METHODS}

This is a descriptive cross-sectional type study of an epidemiological nature performed on the Emergency Services and Mobile Urgency Care Service from the Public Health Service Sector - (SE / SAMU-SUS) of a municipality in the Southwest of Goiás - Brazil

The study was approved by the Research Ethics Committee of the Federal University of Goiás under the protocol $N^{\circ}$ 350\2012. The participants were informed about the study objectives, and those that consented, signed the Free and Informed Consent (IC) form. 
The study was set in a reference hospital in the southwest of Goiás, which establishes its importance and centrality to the region, through its reference to another ten municipalities in the area it covers, while still creating a teaching-learning environment for the universities along with technical courses in the area of health. This is a medium sized unit with 95 registered beds, distributed across a number of specialties, according to the National Registry of Health Establishments

The criteria used for the inclusion of workers were that they had a double work connection with the Municipal Health Secretary and SAMU, in the exercise of their activities at the moment of data collection and could be submitted to the collection of specimens by nasal swab.

Therefore, the initial study population, was constituted of 73 professionals, of these 22 were excluded by refusal, arriving at a total of 51 workers.

Two questionnaires were used as a data collection instrument, one with a sociodemographic and health profile, where factors that could interfere in the collection analysis were investigated, such as airway diseases and the use of antimicrobials/corticoids, besides the practice of hand hygiene in the work environment. The other was a form elaborated in line with recommendations from the NR-32/MT (2005) and Siegel et al., (2007), for collecting complementary data from the laboratory exams.

The data collection was performed during the period of May to June 2012 and counted on the participation of a team made up of 02 researchers appropriately trained for the collection technique and application of the instrument, the questionnaire was applied by means of an interview.

The collection of the clinical specimen from the nasal cavity of workers was performed following the recommendations of the manual for procedures of collection, packing and transport of biological samples from the Public Health Laboratory Dr. Giovanni Cysneiro (FINOTTI et al, 2010). After collection, the exams were immediately sent to the microbiology laboratory of the Municipal Health Secretary, for processing under the direct supervision of the microbiologist.

The analysis of the laboratorial procedures related to the isolation and identification of microorganisms was performed in accordance with Kurtzman \& Fell (1998) and Koneman et al., (2008), by means of automation on a MicroScan from SIEMENS. The tubes with BHI broth that contained the swabs were incubated at $35^{\circ} \mathrm{C}$ for $18 / 24$ hours and then, the samples were smeared onto a selective culture medium. Hence, the colonies that developed on any of the culture mediums employed were firstly identified, according to their macroscopic and morphologic/dyeing characteristics.

The obtained results were employed as screening for the selection of proof of identification. The isolates were grown on MacConkey agar, salt mannitol agar and blood agar through the streak plate method, with the aim of attaining characteristic colonies.

In this sense, the macroscopic colony characteristics of Staphylococcus sp. were submitted to Gram staining and those with microscopic morphology of gram-positive cocci, with predominance of grouping in clusters were cultivated on nutrient agar and incubated at $35^{\circ} \mathrm{C}$ for 24 hours. At the same time, identification was made of the fermented and non-fermented Gram-negative rods by means of identified biochemical detection on the panel of the MicroScan from SIEMENS, used for the microbiological processing and identification of the specimens.

For the suggestive colonies of Staphylococcus $s p$. tests were performed for catalase, free coagulase, deoxyribonuclease (DNase) and lecithinase. The detection of the enzyme catalase has as its objective to characterize the genre Staphylococcus (producers of catalase), and the genre Streptococcus (non-producers of catalase). Therefore, part of the bacterial colony was transferred to a clean slide, dry and degreased, containing a drop of hydrogen peroxide at 3\%, which resulted in the rapid growth of bubbles. According to Koneman et al., (2008), the catalase converts the hydrogen peroxide into water and free oxygen $\left(2 \mathrm{H}_{2} \mathrm{O}_{2} \rightarrow 2 \mathrm{H}_{2} \mathrm{O}+\mathrm{O}_{2}\right)$, which is visually identified by the formation of bubbles.

In turn, the detection of the coagulase enzyme differentiates the staphylococci coagulase producers from non-producers, as this enzyme is capable of converting the fibrinogen present in the plasma into fibrin, thus re-covering the bacterial cells and making them resistant to opsonization and phagocytosis (KONEMAN et al., 2008). Therefore, part of the bacterial culture was transferred to a test tube containing $0.5 \mathrm{~mL}$ of rabbit plasma with the aid of a bacterial loop, incubated at $35^{\circ} \mathrm{C}$ and the readings were taken after 2 to 4 hours of incubation. Some of the $S$. aureus isolates can produce fibrinolysin that degrade fibrin clots and allow for the dissemination of bacteria to the adjoining tissues. These enzymes dissolve the clot during the incubation period at $35^{\circ} \mathrm{C}$. In this context, negative readings after 4 hours of incubation were 
maintained at room temperature and read after 24 hours. The reading was considered positive when there was clotting after 24 hours at room temperature (KONEMAN et al., 2008).

In order to detect the enzyme DNase, part of the colony was smeared in deoxyribonucleic acid, DNase agar, in the form of a circle. The slides were incubated at $35^{\circ} \mathrm{C}$ for 24 hours and the development of a pink coloration around the colonies indicated the production of the enzyme. The authors Koneman et al., (2008) report that Staphylococcus aureus are DNase producers.

In characterizing the activity of lecithinase production, the isolates, once identified were cultivated on Naito agar that contained egg yolk and incubated for 24 hours at $35^{\circ} \mathrm{C}$. The formation of a white and opaque halo around the colonies confirmed the production of the enzyme (ITO et al., 1969). Suspicious colonies were inoculated in a flask with agar nutrient, supplied by the manufacturer MicroScan, incubated at $35^{\circ} \mathrm{C}$ for a period of 18/24 hours, for obtaining a standard bacterial suspension. Posteriorly, the spectrophotometric Reading was taken and the formation of a white and opaque halo around the colonies indicated the production of the enzyme (ITO et al., 1969; MATOS et al., 1995).

To perform the evaluation of the isolates susceptibility profile and the detection of the resistance mechanisms to antimicrobials, the Inhibitory Minimum Concentration method was used, following the recommendations of the CLSI (2009), and the Gram-negative and gram-positive bacteria were submitted to specific biochemical detection and to antibiotics.

All the data were submitted to codification, typed on Microsoft Excel® ${ }^{\circledR}$ worksheets from the 2010 office pack, then descriptive statistics were used for interpretation and analysis of the selfsame data, the results were then presented on tables and in figures.

As agreed upon during data collection, the colonized workers were approached individually, where they received a copy of the results, these were then informed and sent for follow-ups with an infectologist from the Commission for Control of Infection Related to Health Care from the municipality under study.

\section{RESULTADOS}

The population was constituted of 51 health workers. Table 1 shows the sociodemographic profile of the professionals investigated, with a predominance of the technical category in nursing (38\%), female gender (55\%), age group 30 to 39 years, white ethnicity (55\%) and educational level average (37\%).

Table 01. Distribution of the workers from the SE/SAMU - SUS ( $n=51)$, according to the investigated variables. Municipality in the Southwest of Goiás, 2012.

\begin{tabular}{lcc}
\hline Variables & N & \% \\
\hline Qualitative & & 2 \\
Professional category & 1 & 2 \\
Social Worker & 1 & 2 \\
Biomedical scientist & 1 & 12 \\
Biotechnology & 6 & 16 \\
Fire / law enforcement / security guard & 8 & 2 \\
Nurse & 1 & 24 \\
Pharmacist / Biochemist & 12 & 38 \\
Doctor & 20 & 2 \\
Nursing Technician & 1 & 55 \\
Technician in Radiology & & 45 \\
Genre & 28 & 18 \\
Female & 23 & 45 \\
Male & & 25 \\
Age group1 & 9 & 6 \\
$20-29$ & 23 & 2 \\
$30-39$ & 13 & \\
$40-49$ & 3 & \\
$50-59$ & 1 &
\end{tabular}


White

Brown

Black

Education

High school

Incomplete Higher Education

Full Higher Education

Postgraduate studies

\section{Quantitative}

Age (Years)
28

19

4

19

4

15

13
55

37

8

37

8

29

26

\section{Missing: 2}

Regarding the habit of hand hygiene, the 51 participants $(100 \%)$ reported having the habit of hand hygiene, and $46(90.2 \%)$ of hand hygiene before handling an object used by the patient, 38 $(74.5 \%)$ clean their hands after handling objects used by the patient, $44(86.3 \%)$ clean their hands before performing procedures on the patient and 37 $(72.5 \%)$ after performing procedures.

\section{Mean \pm DP} $37.36 \pm 7.90$
Median 36

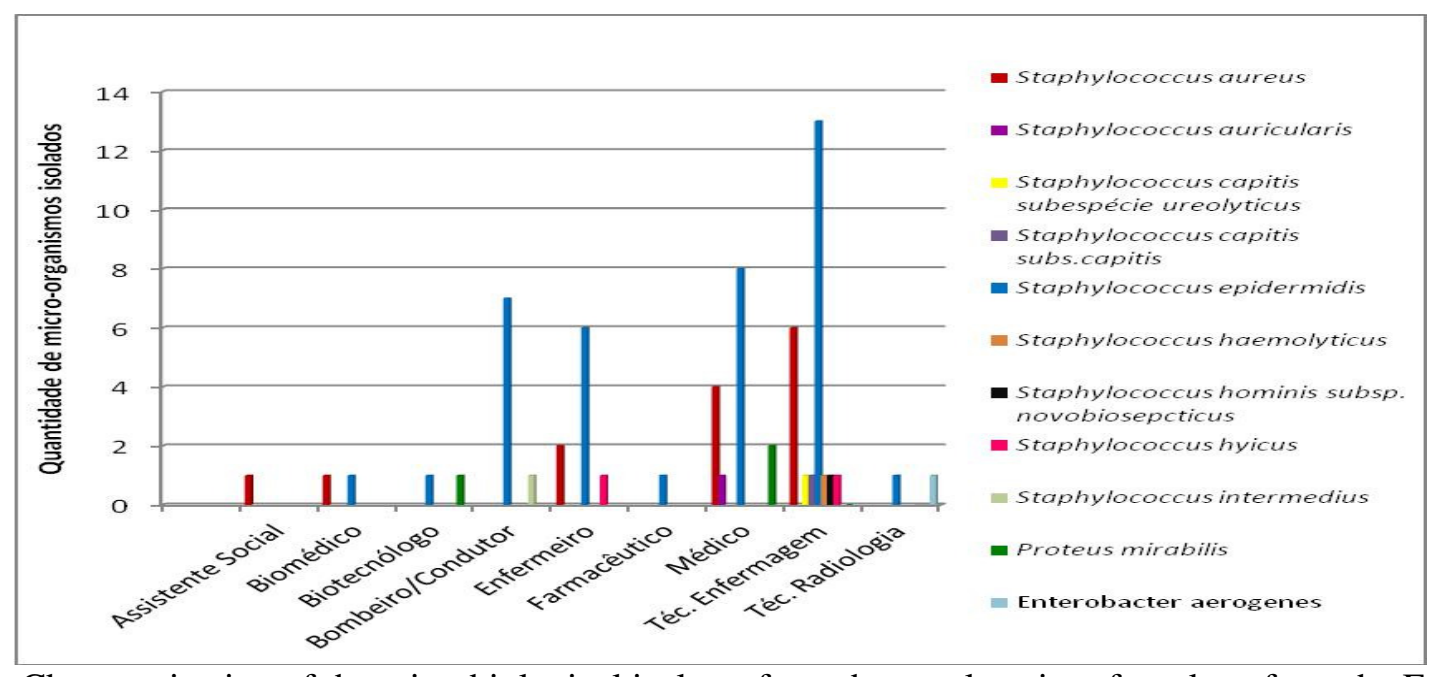

Figure 1. Characterization of the microbiological isolates from the nasal cavity of workers from the Emergency Sector and Mobile Urgency Care Service from SUS. Municipality of Southwest Goiás, 2012.

The profile of susceptibility to antimicrobials of the nasal cavity isolates is presented on Table 2, where one notes that Staphylococcus epidermidis (the most prevalent microorganism) was more sensitive to daptomycin,
Figure 1 shows the microbiota of the nasal cavity, where the profile of the isolates from workers was analyzed. Staphylococcus pidermidis was present in almost all occupational categories 38 (59\%), followed by Staphylococcus aureus 14 (22\%), Proteusmirabilis03 (5\%) and Staphylococcus spp. $(3 \%)$.

Table 2. Susceptibility profile to antimicrobials of isolates in the nasal cavity of workers from, SE/SAMU SUS. Municipality of Southwest Goiás, 2012.

\begin{tabular}{|c|c|c|c|c|c|c|c|c|c|c|c|c|}
\hline \multirow[b]{2}{*}{ ANTIMICROBIALS } & \multicolumn{4}{|c|}{$\begin{array}{l}\text { Staphylococcus } \\
\text { epidermidis } \\
(\boldsymbol{n}=\mathbf{3 8})\end{array}$} & \multicolumn{4}{|c|}{$\begin{array}{l}\text { Staphylococcus } \\
\text { aureus } \\
(\boldsymbol{n}=\mathbf{1 4})\end{array}$} & \multicolumn{4}{|c|}{$\begin{array}{l}\text { Staphylococcus } \\
\text { hyicus } \\
(\boldsymbol{n}=2)\end{array}$} \\
\hline & $\mathbf{n}$ & $\%$ & $\mathbf{n}$ & $\%$ & $\mathbf{n}$ & $\%$ & $\mathbf{n}$ & $\%$ & $\mathbf{n}$ & $\%$ & $\mathbf{n}$ & $\%$ \\
\hline $\begin{array}{l}\text { Amoxicillin / Ac. } \\
\text { Clavulanic }\end{array}$ & 25 & 65.8 & 13 & 34.2 & 12 & 85.7 & 2 & 14.3 & 1 & 50.0 & 1 & 50.0 \\
\hline Ampicillin / Sulbactam & 24 & 63.2 & 14 & 36.8 & 10 & 71.4 & 4 & 28.6 & 1 & 50.0 & 1 & 50.0 \\
\hline
\end{tabular}




\begin{tabular}{lcccccccccccc}
\hline Ampicillin & 4 & 10.6 & 34 & 89.4 & 4 & 28.6 & 10 & 71.4 & 0 & 0 & 2 & 100 \\
Ceftriaxone & 25 & 65.7 & 13 & 34.3 & 12 & 85.7 & 2 & 14.3 & 1 & 50.0 & 1 & 50.0 \\
Ciprofloxacin & 27 & 71.0 & 11 & 29.0 & 14 & 100 & 0 & 0 & 2 & 100 & 0 & 0 \\
Clindamycin & 9 & 23.7 & 29 & 76.3 & 2 & $14, .3$ & 12 & 85.7 & 0 & 0 & 2 & 100 \\
Daptomycin & 38 & 100 & 0 & 0 & 14 & 100 & 0 & 0 & 2 & 100 & 0 & 0 \\
Erythromycin & 5 & 13.2 & 33 & 86.8 & 2 & 14.3 & 12 & 85.7 & 1 & 50.0 & 1 & 50.0 \\
Gentamicin & 33 & 86.8 & 5 & 13.2 & 13 & 92.9 & 1 & 7.1 & 2 & 100 & 0 & 0 \\
Levofloxacin & 27 & 71.0 & 11 & 29.0 & 10 & 71.4 & 4 & 28.6 & 2 & 100 & 0 & 0 \\
Linezolid & 38 & 100 & 0 & 0 & 14 & 100 & 0 & 0 & 2 & 100 & 0 & 0 \\
Moxifloxacin & 36 & 94.7 & 2 & 53 & 14 & 100 & 0 & 0 & 2 & 100 & 0 & 0 \\
Oxacillin & 25 & 65.7 & 13 & 34.3 & 12 & 85.7 & 2 & 14.3 & 1 & 50.0 & 1 & 50.0 \\
Penicillin & 5 & 13.2 & 33 & 86.8 & 6 & 42.9 & 8 & 57.1 & 0 & 0 & 2 & 100 \\
Rifampicin & 35 & 92.1 & 3 & 7.9 & 14 & 100 & 0 & 0 & 2 & 100 & 0 & 0 \\
Synercid & 38 & 100 & 0 & 0 & 14 & 100 & 0 & 0 & 2 & 100 & 0 & 0 \\
Tetracycline & 36 & 94.7 & 2 & 5.3 & 13 & 92.9 & 1 & 7.1 & 2 & 100 & 0 & 0 \\
Sulfamethoxazole / & 33 & 86.8 & 5 & 13.2 & 14 & 100 & 0 & 0 & 2 & 100 & 0 & 0 \\
trimethoprim & 37 & 97.4 & 1 & 2.6 & 12 & 85.7 & 2 & 14.3 & 2 & 100 & 0 & 0 \\
Vancomycin & & & & & & & & & & &
\end{tabular}

\section{DISCUSSION}

Referring to the microorganisms isolated in this study, $59 \%$ of the isolates were S. epidermidis, followed by S. aureus with $22 \%$; however, it was also observed that some of the workers had more than one species of bacterium resistant to different antimicrobials.

Epidemiological studies have shown that healthy individuals can transport between 10 and 24 different strains of $S$. epidermidis. It has even been speculated that colonization by this pathogen is beneficial, as it inhibits the binding of more virulent bacteria, such as $S$. aureus, however, both of these are commonly found colonized on human skin, including in the nasal cavity (FEY; OLSON, 2010). Another study demonstrated this colonization in the nasal cavity of health workers in an ICU, where identification was made of 5 strains of $S$. aureus, and 20 of Staphylococcus negative coagulase (STEFFANI et al., 2010).

The bacteria $S$. epidermidis has become the most common cause of primary bacteremia, of bladder infection, especially in immunocompromised individuals and newborns and those contaminated by medical devices (FEY; OLSON, 2010).

However, $S$. aureus is seen as a microorganism with a greater contagious prowess and is responsible for high rates of IRHC, this is due to its capacity to synthesize a matrix of toxins, besides other factors (FEY; OLSON, 2010; ZAUTNER et al., 2010). The fact that $S$. aureus and $S$. epidermidis are causes of IRHC, from the simplest of cases, such as skin infection, to the most complex that present life threatening risks, such as sepsis and endocarditis, as well as being resistant to antimicrobials, makes the treatment of infections difficult. This substantially reduces the options of treatment and brings forward at the same time the need for new therapeutic treatments (ANDERSON et al., 2012; SILVA et al., 2012).

The collaborators in Noh, et al., (2011), upon identifying the prevalence of bacterial contamination in articles focused on ambulances from a metropolitan region in South Korea, which identified that 429 samples produced 214 that were positive for bacteria, where three were classified as pathogenic (MRSA, MRCoNS, Klebsiella pneumoniae). The authors Rago et al., (2012) detected and analyzed $S$. aureus found in ambulances of the metropolitan region of Chicago USA, and described that $77 \%$ presented resistance to at least 1 antibiotic and $34 \%$ to 2 or more antibiotics. Around $12 \%$ of all isolates were identified as MRSA, while the remaining $88 \%$ were MRSA with a varied antibiogram.

In regards to the profile of susceptibility to antimicrobials of the nasal cavity isolates, this study showed that Staphylococcus epidermidis (most prevalent microorganism) was more sensitive to daptomycin, linezolid and synercid and resistant to ampicillin, erythromycin and penicillin.

The study conducted by Silva and collaborators (2012), where samples were taken from the nasal passage and hands of nursing professionals, found $25.8 \%$ colonized with Staphylococcus aureus, which are $100 \%$ resistant to 
penicillin, the antimicrobial mupirocin (97.6\%) and linezolid (97.6\%), $23.8 \%$ for rifampicin, $42.8 \%$ for erythromycin, intermediary resistance to oxacillin and no resistance to vancomycin. These data corroborate that found by Goudarziet al. (2016).

A recent study conducted by Carvalho et al., (2016), among nursing students who carry out or have completed internships in hospital environments, detected $21.7 \%$ prevalence of Staphylococcus aureus (coagulase positive), where $24.1 \%$ of strains showed resistance to oxacillin and $82.8 \%$ to ampicillin, data close to those found in the study presented herein.

Other authors also verified the susceptibility profile of $S$. aureus, isolated from health professionals in hospitals, regarding antimicrobials and found that from the 74 nasal secretion samples $91.4 \%$ were resistant to penicillin, $44.6 \%$ to erythromycin, $41.9 \%$ to clindamycin, with no resistance found to gentamycin, rifampicin and vancomycin (LOPES et al., 2017). These data differ when it comes to the frequency of resistance, where in our findings $S$. aureus was more resistant to clindamycin and erythromycin than penicillin, however, corroborated in not demonstrating resistance to rifampicin.

Within the total population of this study, a factor that called attention was the fact that $(25 \%)$ of the workers reported using antimicrobials without prescription, where this is an important indicator toward antimicrobial resistance.

Considering the rigor in the dispensing and use of antimicrobials, especially without a prescription, which has the objective of preventing and controlling the mechanisms of resistance developed by microorganisms to these medicines, their inadequate use leads to an acquired resistance of microbial strains (KLEVENS et al., 2006, ANVISA, 2009).

With the intent of averting such conduct, among other aspects, ANVISA elaborated, published and instituted the Resolution of the Collegiate Board of Directors - RDC de $n^{\circ} 44$, with the objective of reducing the inadequate use of antimicrobials by the general population, where these drugs can only be dispensed in pharmacies upon producing a medical prescription (ANVISA, 2009).

In this aspect, one should point out the limitations with regard to compliance with these regulations, among which one finds shortages in both human resources and control methods, particularly when dealing with the degree at which this particular group of drugs is dispensed to the public as well as in health services. However, the results produced in this study point out the need for a continuing education program to bring about worker awareness concerning the risks of selfmedication, as for example, the selection of multiresistant strains.

The act of approaching workers concerning the situation in which they performed the important measure of hand hygiene was seen as appropriate, since such conduct is related to the colonization and cross contamination of microorganisms. A direct examination of the information concerning the workers and the habit of $\mathrm{HH}$, shows all stated that they performed it, however, $26 \%$ did not perform it after handling objects used by the patient and $28 \%$ did not perform $\mathrm{HH}$ after any type of patient procedure.

Evidence indicates the efficiency of hand hygiene for preventing contagion, especially during outbreaks of diseases. The hands are considered as potential vehicles for respiratory pathogens that are disseminated through the mouth (saliva) or nasal mucosa and conjunctiva (FLEISCHMAN et al., 2011). Therefore, professionals from the area of health should know and understand their position as a carrier of microorganisms, in order to contribute toward changes in attitude in professional practice, thus adopting the practice of hand hygiene, performed in a correct manner, that being to use the technique and moments indicated, including the use of appropriate products and recommended substances (FLEISCHMAN et al., 2011; Lima et al, 2015; Lopes et al, 2017).

The results of this study suggest that colonization by $S$. epidermidis and aureus were the most prevalent among the health professionals investigated. A factor that is related to their professional practice, keeping in mind that every day they undergo long periods of care, together with patients and medical hospital material that are potentially colonized. It is believed that the adoption of surveillance measures can reduce the spread of these microorganisms, thus minimizing risk of infection at the study institution. It is noteworthy to mention that actions in a continuing education program can contribute toward higher professional knowledge, technical improvement and the valorization of an organizational culture pertinent to safety in the workplace.

RESUMO: Os desafios pela segurança e qualidade nas instituições de saúde são fenômenos evidenciados por pesquisadores de todo o mundo, em decorrência do despertar da sociedade contemporânea sobre os direitos dos 
trabalhadores e/ou usuários desses serviços. Dessa forma, a detecção de trabalhadores, portadores de micro-organismos patogênicos e multirresistentes, têm sido referidas como uma possível estratégia de prevenção e redução das infecções relacionadas à assistência à saúde - IrAS. Objetivou-se analisar a prevalência da ocorrência de microorganismos da cavidade nasal de trabalhadores e o perfil de susceptibilidade aos antimicrobianos de trabalhadores do Setor de Emergência e Atendimento Móvel de Urgência de um município do sudoeste de Goiás. Foi realizado um estudo transversal de natureza epidemiológica, desenvolvido nos Serviços de Emergência e Atendimento Serviço Móvel de Urgência em um hospital de médio porte de um município do sudoeste de Goiás. A coleta de dados ocorreu entre maio a junho de 2012 e iniciou-se com o esclarecimento quanto ao projeto e posteriormente foi aplicado um formulário aos 51 trabalhadores participantes. Em seguida, coletou-se amostra de espécime da cavidade nasal, por meio de $s w a b$, que foram colocadas em tubos de caldo $\mathrm{BHI}$, e incubadas a $35^{\circ} \mathrm{C}$ por $18 / 24$ horas. Essas amostras foram semeadas em meios de cultura seletivos e processados por automação e as colônias que se desenvolveram foram previamente identificadas e submetidas à triagem para a seleção das provas de identificação. Verificou-se maior prevalência dos micro-organismos, Staphylococcus epidermidis, onde observa-se que ele foi mais sensível a daptomicina, linezolida e sinercida e mais resistente a ampicilina, eritromicina e penincilina, seguido por Staphylococcus aureus resistente a clindamicina e eritromicina. No total de isolados, foi possível analisar o perfil de resistência à antimicrobianos em 38 deles. A adoção medidas de vigilância pode reduzir a propagação desses microrganismos, minimizando riscos de infecções na instituição de estudo. É salutar mencionar que ações de educação continuada podem contribuir com o conhecimento dos profissionais, o aprimoramento técnico e a valorização de uma cultura organizacional de segurança no ambiente laboral.

PALAVRAS-CHAVES: Saúde do Trabalhador. Resistência Microbiana. Segurança do Paciente.

\section{REFERENCES}

ANDERSON, A. S.; SCULLY, I. L.; TIMOFEYEVA, Y.; MURPHY, E.; MCNEIL, L. K.; MININNI, T.; NUÑEZ, L.; CARRIERE, M.; SINGER, C.; DILTS, D. A.; JANSEN, K. U. Staphylococcus aureus Manganese Transport Protein C Is a Highly Conserved Cell Surface Protein That Elicits Protective Immunity Against S. aureus and Staphylococcus epidermidis. The journal of Infection Diseases, Reino Unido: Oxford, v. 205, n. 1, p. 1688-1696, jun 2012. https://doi.org/10.1093/infdis/jis272

AGÊNCIA NACIONAL DE VIGILÂNCIA SANITÁRIA-ANVISA. Resolução da Diretoria Colegiada, RDC No 44 de 17 de agosto de 2009. Brasília, 2009.

Nota técnica $\mathbf{n}^{\circ}$ 1/ 2010: Medidas para identificação, prevenção e controle de infecções relacionadas à assistência à saúde por microrganismos multirresistentes. Brasília, 2010.

Boletim Informativo sobre segurança do paciente e qualidade assistencial em saúde, v.1, n.1, 12 p, Brasília, 2011.

BEZERRA, A. L. Q.; SILVA, A. E. B. C.; BRANQUINHO, N. C. S. S.; PARANAGUÁ, T. T. B. Análise de Queixas Técnicas e Eventos Adversos Notificados em um Hospital Sentinela. Revista de Enfermagem UERJ, Rio de Janeiro, v. 17, n. 4, p. 467-72, out-dez 2009.

CARVALHO, S. M.; ANDRADE, D. F. R.; SOUSA, A. F. L.; VALLE, A. R. M. C.; FREITAS, D. R. J.; NASCIMENTO, G. C.; ANDRADE, D.; WATANABE, E. Nasal colonization with Staphylococcus aureus in nursing students: ground for monitoring. Rev Bras Enferm [Internet], v. 69, n. 6, p, 984-9, 2016.

CASANOVA, C.; ISELIN, L.; STEIGER, N. V.; DROZ, S.; SENDI, P. Staphylococcus hyicus Bacteremia in a Farmer. J Clin Microbiol., Suiça, v. 49, n. 12, p. 4377-4388, dez 2011. https://doi.org/10.1128/JCM.05645-11

CLSI - Clinical and Laboratory Standards Institute. Performance Standards for Antimicrobial Disk Susceptibility Tests. Approved Standards- Tenth Edition, USA, 2009.

COSTA, D. M.. Trabalhadores de um hospital oncológico colonizados por Staphylococcus sp. resistentes à meticilina: aspectos microbiológicos epidemiológicos. 2012. 137 p. Dissertação (Mestrado em Enfermagem), Faculdade de Enfermagem da Universidade Federal de Goiás, Goiânia, 2012. 
CRUZ, E. D. A.. Staphylococcus aureus e Staphylococcus aureus resistente à meticilina em trabalhadores de um hospital universitário: colonização e crenças em saúde. 2008 187p. Tese (Doutorado em Enfermagem). Escola de Enfermagem de Ribeirão Preto, Universidade de São Paulo, Ribeirão Preto, 2008.

CRUZ, E. D. A.; PIMENTA, F. C.; PALOS, M. A. P.; SILVA, S. R. M.; GIR, E. Higienização de Mãos: 20 anos de divergências entre a prática e o idealizado. Ciencia y Enfermeria, Chile, v. 1, n. 1, p. 33-38, 2009. https://doi.org/10.4067/S0717-95532009000100005

CURTIS, L. T.. Prevention of hospital-acquired infections: review of non-pharmacological interventions. Journal of Hospital Infection, Londres, v. 69, n. 3, p. 204-219, jul. 2008. https://doi.org/10.1016/j.jhin.2008.03.018

DE LIMA, F. H. A. Perfil de infecção de recém-nascidos em unidade de cuidados intermediário e intensivo neonatal: aspectos relacionados. Goiânia, 2012. Dissertação (Mestrado Profissional), Convênio Universidade Federal de Goiás, Goiânia, 2012.

FEY, P. D; OLSON, M. E. Current concepts in biofilm formation of Staphylococcus epidermidis. Future Microbiol., Londres, v. 5, n. 6, p. 917-933, 2010. https://doi.org/10.2217/fmb.10.56

FINOTTI, A; BASTOS, A. L. D.; ACIOLI, A. S. D. N.; RAMOS, C. H.; ACIOLI, J. E. C.; SANTALUCIA, M.; CUNHA, M. J. D.; ALMEIDA, R. M. D.; ALVES, S. L. D. Á.; CHAVEIRO, V. I. W. D. O. Manual de procedimentos para coleta, acondicionamento e transporte de amostras biológicas do Laboratório de Saúde Pública Dr. Giovanni Cysneiro. Secretaria Estadual de Saúde. Goiânia, 2010.

FLEISCHMAN, D. S.; WEBSTER, G. D.; JUDAH, G.; de BARRA, M.; AUNGER, R.; CURTIS, V. A. Sensor recorded changes in rates of hand washing with soap in response to the media reports of the H1N1 pandemic in Britain. BMJ Open, Londres, v. 1, p. e127, 2011. https://doi.org/10.1136/bmjopen-2011-000127

GOUDARZI, G.; TAHMASBI, F.; ANBARI, K.; GHAFARZADEH, M. Distribution of Genes Encoding Resistance to Macrolides Among Staphylococci Isolated From the Nasal Cavity of Hospital Employees in Khorramabad, Iran, Iran Red Crescent Med J, v. 18, n. 2, p. e25701, 2016.

HAFEZ, M. A. E. KHALAF, G. N.; AHMADY, M. E.; AZIZ, A. A. E.; HASHIM, A. E. G. An outbreak of meticillin resistant Staphylococcus epidermidis among neonates in hospital in Saudi Arabia. J Infect Dev Ctries, Itália, v. 5, n. 10, p. 692-699, 2011.

ITO, I. Y.; BARACCHINI, O. Emprego de gema de ovo no isolamento de Staphylococcus. Ann. Microbiol., Ribeirão Preto, São Paulo, v. 6, p. 189-92,1969.

KLEVENS, R. M.; MORRISON, M. A.; FRIDKIN, S. K.; REINGOLD, A.; PETIT, S.; GERSHMAN, K.; RAY, S.; et. al.. Community-associated methicillin-resistant Staphylococcus aureus and healthcare risk factors. Emerg Infect Dis., USA: Atlanta, v. 12, n. 1, p. 1991-1993, 2006. https://doi.org/10.3201/eid1212.060505

KONEMAN, E. W. Diagnóstico microbiológico: texto e atlas colorido. 6 ed., Rio de Janeiro: Guanabara Koogan, 2008. 1565 p.

KURTZMAN, C. P.; FELL, J. W. The yeasts-a taxonomic study. Fourth revised and Enlarged edition. 1998. 1076 p.

LIMA, M. F. P.; BORGES, M. A.; PARENTE, R. S.; JÚNIOR, R. C. V.; DE OLIVEIRA, M. E. Staphylococcus aureus e as infecções hospitalares - revisão de literatura. Revista UningáReview, v.21, n.1, p.32-39, 2015. 
LOPES, A. C. S.; OLIVEIRA, A. C.; SILVA, J. T.; PAIVA, M. H. R. S. Adesão às precauções padrão pela equipe do atendimento pré-hospitalar móvel de Belo Horizonte, Minas Gerais, Brasil. Cad. Saúde Pública, Rio de Janeiro, v. 24, n. 6, p. 1387-1396, 2008. https://doi.org/10.1590/S0102-311X2008000600019

LOPES, L. P.; PIO, S. P. M.; REINATO, L. A. F.; GASPAR, G. G.; PRADO, M. A.; GIR, E. Staphylococcusaureus em profissionais de enfermagem e o perfil de suscetibilidade do microrganismo aos antimicrobianos. Texto Contexto Enferm, v. 26, n. 2:e00400016, 2017.

MALTA, D. C.; MASCARENHAS, M. D. M.; BERNAL, R. T. I.; ANDRADE, S. S. C. A.; NEVES, A. C. M.; MELO, E. M.; JUNIOR, J. B. S. Causas externas em adolescentes: atendimentos em serviços sentinelas de urgência e emergência nas Capitais Brasileiras - 2009. Rev. Ciência e Saúde Coletiva, Rio de Janeiro, v. 17, n. 9, p. 2291-2304, 2012. https://doi.org/10.1590/S1413-81232012000900011

NOH, H.; SHIN, S. D.; KIM, N. J.; RO, Y. S.; OH, O. S.; JOO, S. I.; KIM, J. I.; ONG, M. E. H. Risk stratification based surveillance of bacterial contamiination in metropolitan ambulances. J Korean Med Sci., Korea, v. 26, n. 1, p. 124-130, 2011. https://doi.org/10.3346/jkms.2011.26.1.124

OLIVEIRA, A. C; DE PAULA, A. O. Monitoração da adesão à higiene de mãos: uma revisão de literatura. Acta Paul Enferm., São Paulo, v. 24, n. 3, p. 407-413, 2011. https://doi.org/10.1590/S010321002011000300016

OMS - Organização Mundial da Saúde. Manual para Cirurgia Segura da OMS (Primeira Edição), Genebra, Organização Mundial da Saúde, 2008.

Diretrizes da OMS sobre higienização das mãos na assistência à saúde (versão preliminar avançada): Resumo. Genebra: 2009.

PAVÃO, A. L. B.; ANDRADE, D.; MENDES, W.; MARTINS, M.; TRAVASSOS, C. Estudo de incidência de eventos adversos hospitalares, Rio de Janeiro, Brasil: avaliação da qualidade do prontuário do paciente. Rev Bras Epidemiol., São Paulo, v. 14, n. 4, p. 651-661, 2011. https://doi.org/10.1590/S1415-790X2011000400012

PALOS, M. A. P.; SILVA, D. V. B.; GIR, E.; CANINI, S. R. M. S.; ANDERS, P. S.; LEÃO, L. S. N. O.; PIMENTA, F. C. Microbiota das mãos de mães e de profissionais de saúde de uma maternidade de Goiânia. Revista Eletrônica de Enfermagem, Goiânia, v. 11, n. 3, p. 573-578, 2009.

https://doi.org/10.5216/ree.v11.47111

RAGO, J. V. Detection and analysis of Staphylococcus aureus isolates found inambulances in the Chicago metropolitan área. Am. Journal of Infection Control, Nova York, v. 40, p. 201- 205, 2012. https://doi.org/10.1016/j.ajic.2011.08.021

SIEGEL, J. D.; RHINEHART, E.; JACKSON, M.; CHIARELLO, L. Helth Care Infection Control Practices Advisory Committee. Guideline for Isolation Precautions: preventing transmission of infectious agents in healthcare settings. Am J Infect Control., Nova York, v. 35, n. 10, p. S65-S164, 2007.

SILVA, E. C. B. F.; SAMICO, T. M.; CARDOSO, R. R.; RABELO, M. A.; BEZERRA NETO, A. M.; MELO, F. L.; LOPES, A. C. S.; ACA, I. S.; MACIEL, M. A. V. Colonização pelo Staphylococcus aureus em profissionais de enfermagem de um hospital escola de Pernambuco. RevEscEnferm USP, v. 46, n. 1, 132-7, 2012. https://doi.org/10.1590/S0080-62342012000100018

STEFFANI, J. A.; GALHOTO, A.; IAGHER, F.; BAÚ, M.; STUMPF, C. C. Identificação de microorganismos em profissionais e superfícies de uma unidade de terapia intensiva. Rev. Moreira Jr, São Paulo, v. 69, n. 11, p. 1-7, 2010. 
WOLF, R.; LEWIS, D.; COCHRAN, R.; RICHARDS, C. Nursing Staff Perceptions of Methicillin-Resistant Staphylococcus aureus and Infection Control in a Long-Term Care Facility. Journal of the American Medical Directors Association, USA: Saint Louis, v. 9, n.5, p. 342-346, jun. 2008.

https://doi.org/10.1016/j.jamda.2008.02.003

ZAUTNER, A. E.; KRAUSE, M.; STROPAHL, G.; HOLTFRETER, S.; FRICKMANN, H.; MALETZKI, C.; KREIKEMEYER, B.; PAU, H. W.; PODBIELSKI, A. Intracellular Persisting Staphylococcus aureus Is the Major Pathogen in Recurrent Tonsillitis. Plos One, USA: California, v. 5, n. 3, p. 9452- 9462, 2010. https://doi.org/10.1371/journal.pone.0009452 